\title{
Evaluation of General Public's Knowledge and Perception of Appropriate Antibiotics use in Salem District
}

\author{
Rahul Radhakrishnan, Jaykar Balasundaram, Arul Balasubramaniam, Guru Gunasekaran \\ Department of Pharmacy Practice,Vinayaka Missions College of Pharmacy, Salem, Tamil Nadu, INDIA.
}

\begin{abstract}
Objective: The objective of this study was to evaluate the general population's current knowledge, expectations, and usage of antibiotic in Salem district of Tamil Nadu. Method: The survey was developed based on previous researches. The survey was initially developed in English and then translated to Tamil. The survey gathered demographic information and collected data on knowledge, preferences, expectations, and antibiotic usage in population of Salem district. Results: Survey has 142 participants in which 92 responded well representing a $65 \%$ response rate. $63.9 \%$ of respondents believed that they could stop taking antibiotics if their symptoms of infection improved. Around half of the population $(43.5 \%)$ believed antibiotics are effective for most of the colds and over a half of respondents (55.4) stated that, they prefer to keep antibiotics at home for emergencies. Approximately a one third of respondent (36.1\%) would give their antibiotics to a family member if they caught an infection, $14.2 \%$ of respondents identified that, and they have bought an antibiotic from community pharmacies at Salem without a prescription. Conclusion: The study showed that the population in Salem has a number of misconceptions relating to appropriate antibiotic use, particularly relating to use of antibiotics for treatment of viral infections. As antibiotics are widely used in Salem as well as India, proper education should be given about rational use of antibiotics to the public.
\end{abstract}

Key words: Rational Use, Antibiotics, Prospective study, Public Knowledge, Appropriate.

\section{INTRODUCTION}

Evaluation of the general population's understanding of appropriate antibiotic use has demonstrated gaps in knowledge. Studies completed nationally have demonstrated an alarming number of patients believe that antibiotics can be used in the treatment of viral infections and other self-limited illnesses.

Despite misconceptions, patients often reported a high expectation of receiving antibiotics from their health care providers, several trials have demonstrated a positive correlation between patient expectations and Physicians prescription.

Education to physicians, patients, and the public has been identified as the most effective to reduce inappropriate antibiotic use.

In order to implement such strategies in Salem, a baseline assessment of knowledge, attitudes and current antibiotic uses by the public is to be evaluated.

\section{STUDY OBJECTIVE}

The objective of this study was to evaluate the general population's current knowledge, expectations, and uses of antibiotic in Salem District of Tamil Nadu.

\section{METHODS}

Design: Cross-sectional survey
DOI: 10.5530/ijopp.10.2.21

Address for

correspondence:

Rahul $\boldsymbol{R}$,

$4^{\text {th }}$ eear Pharm D, Vinayaka

Mission's College of Pharmacy, Vinayaka Missions University, Yercaud Main road, Kondapanaickenpatti, Kannankurichi (PO)

-636008 Salem, Tamilnadu, INDIA

Phone no: +91 8281231295

E-mail: elizabethphoeba1892@ gmail.com

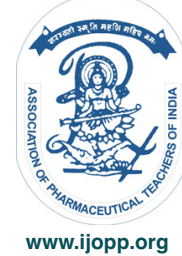


Survey Development: The survey was developed based on previous researches. The survey was initially developed in English and then translated to Tamil language using a process of back- translation. The survey was reviewed by two pharmacists with expertise in survey development and based on the feedback from the pilot study, the survey was revised.

Survey Content: The survey gathered demographic information and collected data on knowledge, preferences, expectations, and current antibiotic usage of general population. The criteria's evaluated in the survey are described in Table 2 and 3.

Participants: Members of the general population living in Salem, who were above 18 years of age were eligible to be participate in the study.

Data collection: Participants are selected among the hospital visitors, person visiting community pharmacy and patient bystanders in selected hospitals of Salem District.

\section{RESULTS}

\section{General}

In the Survey 92 out of 142 participants responded to the survey representing $65 \%$ response rate.

Baseline characteristics of the 96 respondents were included in this study and are outlined in Table 1.

\section{Knowledge of Appropriate use of Antibiotics}

The proportion of participants who correctly respondent to questions about knowledge of appropriate antibiotic use are outlined in Table 2.

- $34.6 \%$ of participants indicated that antibiotics were effective for treating infections caused by viruses.

\begin{tabular}{ccc}
$\begin{array}{c}\text { Table 1: Demographics } \\
\text { CHARACTERISTICS }\end{array}$ & NUMBER & PERCENTAGE \\
\hline \multicolumn{2}{c}{ Gender } & \\
Male & 39 & $42 \%$ \\
Female & 53 & $58 \%$ \\
& LEVEL OF EDUCATION & \\
Primary School & 32 & $35 \%$ \\
High school & 38 & $41 \%$ \\
College/University & 18 & $19 \%$ \\
Post Graduate & 4 & $0.04 \%$
\end{tabular}

\begin{tabular}{|c|c|c|}
\hline Statement & $\mathbf{N}$ & $(\%)$ \\
\hline $\begin{array}{c}\text { Most cold, cough, and flu illnesses are caused } \\
\text { by viruses }\end{array}$ & 76 & 80.5 \\
\hline Antibiotics are effective for most colds & 40 & 43.5 \\
\hline $\begin{array}{c}\text { Antibiotics are effective for treating infections } \\
\text { caused by bacteria }\end{array}$ & 62 & 67.5 \\
\hline $\begin{array}{l}\text { Antibiotics are effective in treating infections } \\
\text { caused by viruses Not receiving an antibiotic } \\
\text { for cold, cough, and flu symptoms }\end{array}$ & 32 & 34.6 \\
\hline will lengthen the duration of illness & 40 & 43.8 \\
\hline $\begin{array}{l}\text { If taken too often, antibiotics are less likely to } \\
\text { work in the future }\end{array}$ & 71 & 77.8 \\
\hline $\begin{array}{l}\text { You can stop taking antibiotics if your } \\
\text { symptoms of infection improved }\end{array}$ & 58 & 63.9 \\
\hline Antibiotics can cure all types of infections & 54 & 58.6 \\
\hline Used antibiotics within past 5 years. & 88 & 95.8 \\
\hline $\begin{array}{l}\text { Bought antibiotics without prescription from } \\
\text { community pharmacy }\end{array}$ & 13 & 14.2 \\
\hline
\end{tabular}

- $63.9 \%$ of participants believed that they could stop taking antibiotics if their symptoms of infection improved.

- Around half of the population (43.5\%) believed that antibiotics are effective for most colds and a similar proportion (43.8\%) stated that not receiving an antibiotic for cold, cough, and flu symptoms will lengthen the duration of illness.

\section{Antibiotics Preferences and Expectations}

Details on participant preferences and expectations relating to antibiotic use are outlined in Figure 1.

- The majority (61.7\%) of respondents said that if their physician did not prescribe an antibiotic for their infection, they would consult another physician to prescribe it for them.

- Over half (55.4\%) of respondents stated that they prefer to keep antibiotics at home in case of emergency.

- Approximately a one third of participants (36.1\%) would give their antibiotics to a family member if they caught an infection.

\section{Antibiotic Usage}

- Almost all respondents (95.8\%) used an antibiotic within past 5 years and $47.2 \%$ of participants had used an antibiotic within the past 6 months.

- Although antibiotics require a prescription to be dispensed, $14.2 \%$ of respondents identified that they have bought an antibiotic from community pharmacies in Salem District without a prescription within the last 5 years. 
Figure 1: Antibiotics Preferences and expectations.

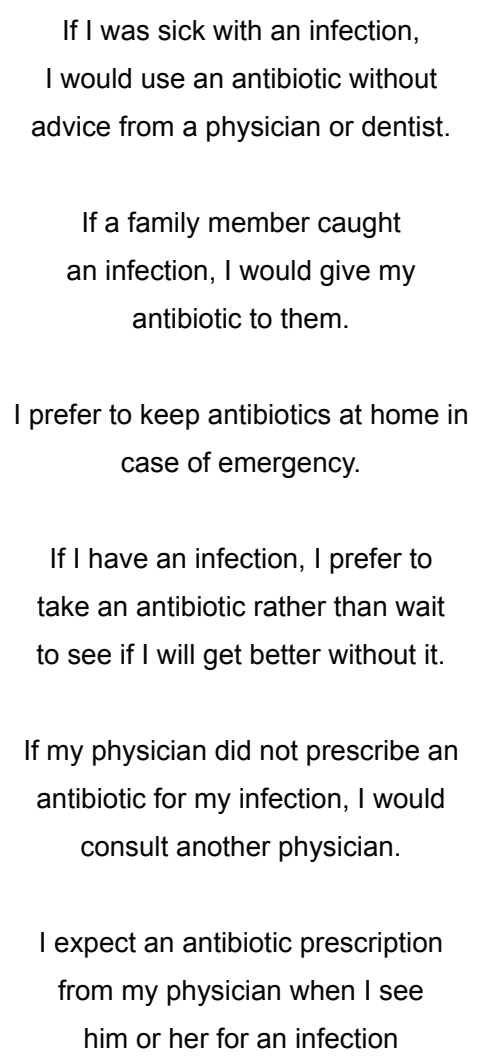

\section{CONCLUSION}

- This is the first study to assess the general public's knowledge and perception of appropriate antibiotic use in Salem.

- Results of the study showed that the population in Salem has a number of misconceptions relating to appropriate antibiotic use particularly relating to use of antibiotics for treatment of viral infections.

- As antibiotics are widely used in Salem, educational interventions about appropriate antibiotic use are needed.

\section{ACKNOWLEDGEMENT}

We Express our heartfelt gratitude to our professors of Pharmacy Practice, friends, clinical pharmacist

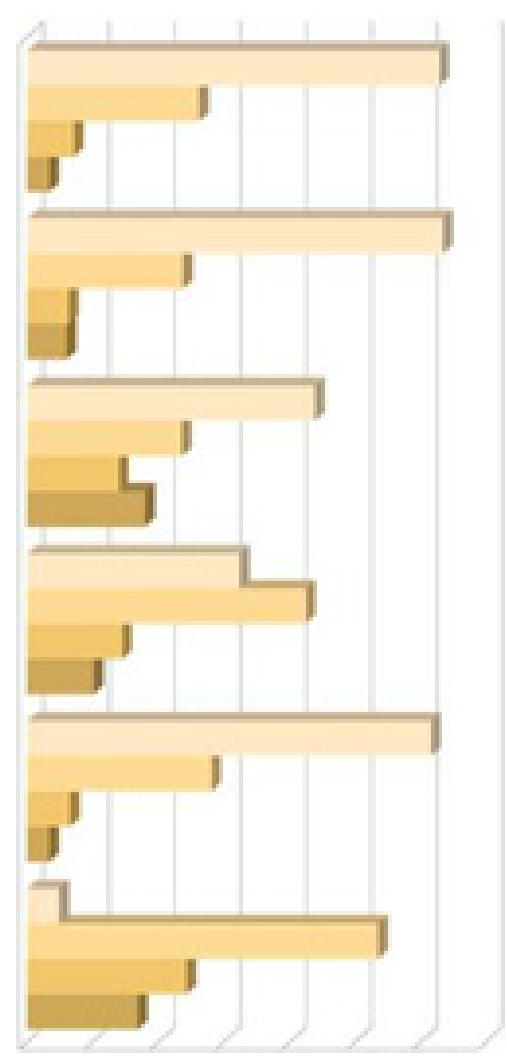

and Doctors of VMKV medical college Salem, Government Mohan Kumaramangalam, Medical college Salem, Tulsi pharmacy salem, and also thanks to paticipants of this cross-sectional Study.

\section{CONFLICT OF INTEREST}

None

\section{REFERENCES}

1. Ling Oh A. Public knowledge and attitudes towards antibiotic usage: a crosssectional study among the general public in the state of Penang, Malaysia. J Infect Dev Ctries. 2011;5(5).

2. Huang SS. Parental knowledge about antibiotic use: results of a cluster randomized, multi-community intervention. Paediatrics. 2007;119(4):698-706. 